\title{
Lease financing of Bangladesh: A descriptive analysis
}

\author{
Md. Ariful Islam ${ }^{1}$, Md. Rayhan Islam ${ }^{2}$, Mahmudul Hasan Siddiqui ${ }^{3}$ \\ ${ }^{1}$ BASIC Bank Limited, Khulna, Bangladesh \\ ${ }^{2}$ Business Administration Discipline, Khulna University, Khulna-9208, Bangladesh \\ ${ }^{3}$ Unilever Bangladesh Limited, Gulshan-1, Dhaka-1212, Bangladesh
}

Email address:

arifrussell@yahoo.com (M. A. Islam), rayhan_07@yahoo.com (Md. Rayhan Islam), mhs.sadi@gmail.com (M. H. Siddiqui)

To cite this article:

Md. Ariful Islam, Md. Rayhan Islam, Mahmudul Hasan Siddiqui. Lease Financing of Bangladesh: A Descriptive Analysis. International Journal of Economics, Finance and Management Sciences. Vol. 2, No. 1, 2014, pp. 33-42. doi: 10.11648/j.ijefm.20140201.15

\begin{abstract}
Leasing industry is one of the flourishing sector of Bangladesh. The leasing companies on the average are doing pretty well since inception in this country. Leasing has gained its popularity for several reasons. The first and most important of all is that leasing can be thought of as an alternative source of fund which is most of the cases cheaper, and for the companies which don't have a high credit rating or a visible positive past track record, this may be the main source of financing. Another thing is, lease is an alternative to investment. If you need a particular asset for running or expanding your business, you may choose to lease it rather than purchase it. And you can cancel the lease options in the face of changing macroeconomic factors, such as obsolescence, new technologies, changing business needs or market conditions etc. Lease is nowadays treated by the developed markets as a provider of $100 \%$ financing and they have a notion that lease displaces debt. Leasing actually reduces the leverage needs of a firm. We can understand that the leasing market is still very small in Bangladesh and the actual potential market is highly untapped. Since people are not well aware of different types of lease products, they look for other alternative before leasing. But now it's time for us to break away from tradition and utilize leasing in our businesses fully so that we can realize its benefits. We believe that leasing sector in Bangladesh will grow, as people become more knowledgeable and more willing to look for alternative sources of financing.
\end{abstract}

Keywords: Leasing, Industry, Leverage, Bank, Financial Institution, Finance

\section{Introduction}

\subsubsection{A Brief History of Leasing in Bangladesh}

The idea of setting up an equipment leasing company in Bangladesh was first discussed in a meeting of the shareholders of Industrial Promotion and Development Company of Bangladesh Limited (IPDC) held in Washington D.C. in November 1983. The International Finance Corporation (IFC) as one of the shareholder in IPDC, and a pioneer in the promotion of leasing operation in the developing countries came forward to assist IPDC in setting up the leasing company in Bangladesh.

The Korea Development Leasing Corporation (KDLC) of which IFC was a shareholder, was identified as a technical partner for the proposed venture. Joint appraisal missions quickly followed and with the active support of the Government of Bangladesh, and the participation by local and foreign institutional shareholders, the first equipment leasing company now known as Industrial Development Leasing Company of Bangladesh Limited
(IDLC) was set up in 1984. The company started operation in February 1986.

IDLC is the pioneer of leasing industry in Bangladesh. It is a joint venture public limited company with the multinational collaboration of international development finance institutions, commercial banks, insurance company, and foreign leasing corporation. During the past 18 years of its operation, IDLC has played a catalytic role in providing alternative source of term and capital asset financing to the private sector. IDLC's primary focus has been in the area of 3-5 year term financial leasing with particular emphasis on Balancing, Modernization, Replacement, and Expansion (BMRE) of existing units. With its pioneering vision IDLC has not only established lease financing as an efficient and quality financial service but also laid the foundation for the creation of 10 other leasing companies in the country.

The emergence of the leasing companies, since inception successfully created public awareness about lease financing, 
and definitely made significant progress with the objective of assisting the development of productive enterprises. Today lease financing has grown to be an Industry of BDT 4.5 billion per annum.

\subsubsection{Financial Sector Scenario in Bangladesh}

The banking system of the country continues to be under pressure of non-performing classified loans (NPL) at an alarmingly high level of 31.49 percent of the total loan portfolio. Although the situation marginally improved in the recent past, the existence of huge non-performing loan almost exhausted the reserves and created significant capital deficiency in the interest rate structure, the new government has reduced the bank rate from existing 6.0 percent to a new level of 5.0 percent. Moreover, effective interest rate of the government owned fixed income securities have also been reduced by $1.5-2.0$ percent. In some of the priority sectors like export and agro-based industries the interest rates have been slashed by 2-3 percent. However, the market may take more time to experience an overall downward shift in the interest rate structure, since the presence of huge NPL increases the cost of the fund to a great extent.

\subsubsection{Lease Industry Scenario in Bangladesh}

For the last three years, the leasing industry experienced average growth rate of around 30 percent, although the market penetration remains very low range of 3-4 percent of medium term financing. With the new leasing companies and active participation of commercial banks in the leasing business, the overall competition level has increased substantially during the year. Withdrawal of initial depreciation allowance on asset in 1998 continues to adversely affect the profitability of leasing companies. However, among visible non-functioning of development financial institutions (DFIs), ailing capital market and lack of interest of commercial banks in term financing, the leasing industry remains only vibrant financial intermediaries for the medium term financing with less than 5.0 percent non-performing loans.

During the year, the weak of constant demand and persuasion by the NBFIs for their increased cost of fund for huge amount of non operational fund tied up in the form of FDRs to meet the Statutory Liquidity Requirement (SLR), the Central Bank has reduced the SLR rate from 10 percent of total liabilities to 5 percent, a welcome supportive move for the industry as a whole.

\subsection{Statement of the Research Problem}

Now-a-days evaluation of leasing companies is very important in our country to get its services with satisfaction and less Risk. It helps investors, depositors, lessee, regulatory authority, and the management to get a quick idea about the financial and managerial aspects of business units' performance. It is a single measure by which users can get an instant idea about relative performance (risks and return) of business institutions. Since the single measure does not require complex finance and economic knowledge to be understood, it is very popular and widely practiced in developed economy as well as developing one like ours.

It is developed for bond market and for determining credit worthiness of business institutions. International rating agencies (e.g. Moody's Investors Service, Standard \& Poor's Corporation, and Value Line etc.) have started ranking financial institutions, which reflects soundness of its operation and risk-return aspects. These international ranking agencies rank only large institutions, which operate internationally. Unfortunately, domestically operated financial institutions are outside of the network of these.

The Credit Rating Information and Services Limited (CRISL) has established under the Credit Rating Companies Rules - 1996 to do this job in Bangladesh, but due to some legal barriers they did not able to present any rating neither financial Instruments nor financial institutions. It is important to mention here that the Securities and Exchange Commission (SEC) has announced the terms of the rules, "no issue of public debt or issue of share at a premium or issue of share at a premium or issue of right share shall be made by a company unless the issue is rated by a credit rating company and declaration about such rating is given in the prospectus or right share offer document as the case may be."

\subsection{Objectives of the Study}

At present, there are 22 leasing companies in Bangladesh - mostly joint venture and privately owned A large base of foreign and local stakeholders are now interested in leasing companies' matters. The investors (owners), depositors, lessees, management (lessor), the regulator, as well as the government are also anxious for the performance (riskreturn) of leasing companies. They need to know the relative performance of the non-bank financial institutions in Bangladesh.

The primary purpose of this study is to analyze the financial statements of selected (sampled) leasing companies operating in Bangladesh. The ultimate objective of this study is to evaluate the performance of leasing companies through analyzing relevant financial factors to prepare a year-wise overall (composite) position of the leasing companies based on research findings. These main objectives can be further subdivided into the following specific objectives:

To analyzes position, employment generation position, operating performance position, profitability and market position and debt-utilization position of selected leasing companies in Bangladesh.

- To analyze the risk and growth rate of leasing companies respectively

- To analyze Financial soundness of leasing companies

- Finally, a year-wise overall (composite) position of leasing companies to be prepared based on their performance evaluation and a technical interpretation 
of the research findings are aimed to incorporate in this study;

\subsection{Methodology of the Study}

\subsubsection{Research Design}

Overall design of the proposed research work includes the identification of the research problem, sample design, method of the research work, data collection, data analysis, and interpretations of the research findings. In the introductory chapter, the purpose of the study, objectives are developed, and described. Now the rest pants of the research design are stated as follows:

\subsubsection{Sample Selection}

There are 22 leasing companies in Bangladesh now. But in primary investigation, it is found that all of them are not in operation. Some are found in operation from early 2000 and they did not publish their financial reports till now. There are some commercial banks that are engaged in leasing business. Now, commercial banks are emerged as competitors of leasing companies. However, this study will be limited only among the leasing companies' performance operating in Bangladesh, as they are the market leaders in leasing business of our country. To cover the maximum lease market share (about 80\%) in the research, 8 leasing companies are included in this study based on their higher lease market share.

\subsubsection{Nature and Sources of Data}

The data used in the study are theoretical in nature. This study is based on the financial data taken from the financial statements of various leasing companies operating in Bangladesh. The items incorporated in the financial statements are taken in purpose of calculating financial ratio specific data sources are also mentioned in respective places i.e. tables, figures, etc. Thus, the study is mainly based on secondary data. Some data are also used, which are not published yet. However, sources of data identify it for reliability, and meaningful interpretation.

\subsubsection{Collection of Data}

The present study analyzed financial data of leasing companies in Bangladesh, which are collected from the financial statements of various leasing companies. These data are secondary in nature.

\subsubsection{Method of Data Analysis}

Financial analysis technique is used for calculating various relationships among financial variables incorporated in financial statements of leasing companies. This analysis is shown in the Table-to-Table Evaluation of performance of leasing companies, their operational efficiency, growth rate etc. are calculated through ratio techniques. However, guidelines for interpreting.

\subsection{Scope of the Study}

All leasing companies in Bangladesh have legal bindings to prepare the Financial Statements at least annually. It indicates the financial health of leasing companies. It generally incorporates the Balance Sheet, Income Statement, and Cash-flow Statement. One researcher, if so desires, can collect the financial statements of leasing companies in Bangladesh paying some efforts. One such attempt was taken for all leasing companies were made available. Basically, it gave me the scope to undertake the present research. The range of this study is limited only in the analysis of financial statements and computation of financial ratios with the data incorporated in the financial statements, which is called the Fundamental Analysis and the analysis of managerial as well as market forecasting aspects (called technical analysis) of leasing companies in not included in this study.

\subsection{Significance of the Study}

The ultimate objective of this study is to evaluate the leasing companies operating in Bangladesh in order to judge their relative performance. The leasing companies, in terms of profitability/operating performance, risk-growth indicators. Thus, investors (owners), lessees, depositors, competitors, other service seeker-s, can choose their appropriate leasing company to create long-term relationship. This ranking may also help both the management/lessor of leasing companies and stakeholders in many ways. Some of these are stated as follows:

- Leasing companies having relatively volatile (unstable position) in the industry are more risky (uncertain) for depositors, and investors. They require higher risk premium for their deposits and investments respectively. Thus this gives them an idea about the risk-return criteria of the leasing company so that they can demand appropriate return from their deposits/investments.' On the other hand, good ranking leasing company can offer lower deposit rate because of their low risk. Thus, they can reduce their operating cost and they're by increase profits by

- Large number of lessees, fund managers do not know leasing companies' relative performance. This research helps them to focus on areas where they can add values.

- Positions brings risk-reword opportunities for leasing companies. The leasing companies that are sliding try to cash in on their historic reputation and borrow for less than they should.

If management of a leasing company finds that their ranking is falling over years, they can able to search the reasons and can take appropriate measures to keep the company's position better.

In the light of these above significance, it can be said that this study will have a wide range of use in the leasing sector of Bangladesh. Management of leasing companies as well as general people (stakeholders) can use this research in making their right business decisions to maximize profit and minimize risks. 


\subsection{Limitations of the Study}

In conducting this research, some limitations were felt, which should not be hided, are stated as follows:

- Due to the limitation of time it was not possible to cover all the details of the study.

- For the confidential reason many leasing companies did not provide sufficient information for this study.

- Leasing business in Bangladesh is not well organized like banking and that is why collection of information from such unorganized sector was quite tough.

- This study is basically based on the financial data incorporated in the Financial Statements of respective leasing companies, and the managerial as well as lease market forecasting aspects information are not included, which may give a distorted picture of the reality. This limitation can also lead to the research findings far away from explaining the exact present situation of leasing companies presently operating in Bangladesh;

- This study is mainly affected by all the limitations of financial statements, and also by the limitations of financial ratios

\subsection{Definition of Terminology}

The operational terminology of this dissertation is given below that carries significant meaning for the present study.

Leasing Company: The non-banking financial institutions, which are licensed by Bangladesh Bank under the Financial Institutions Act, 1993.

Back-to back lease: a lease in matching in major terms with a lease-out of the same equipment, for example, a lease by a manufacturer or dealer of his stock to a leasing company, who lease it back to the manufacturer or dealer, either to be used by the latter, for further subletting.

Bangla Lease: In association of leasing companies in Bangladesh, established in December 1999 namely "Bangladesh Leasing and Finance Companies Association" also called Bangla lease.

Broker: An intermediary who arranges leases deals.

Collateral: Literally, means secondary or subordinate. Collateral security means an additional security. In a lease, the asset leased is a collateral security.

Consortium Lease: A lease where a number of lessors participate as joint- lessors.

Economic life: The estimated period during which the asset is expected to be economically usable by one or more users, with normal repairs and maintenance, for the purpose for which it is originally intended.

Evaluating a leasing company's performance: It will include, how can we use a leasing company's financial statements- particularly its Balance Sheet and Income Statement- to evaluate, how well the leasing company is performing?

Equity Participant: In a leveraged lease the lessor is the equity participant. Also called owner participant, trust owner, grantor owner.

Fair Market Value: At the maturity of lease, fair market value is the price a willing buyer will pay to a willing seller for the equipment on a as is where is" base.

Fair Rental: The expected rental for equipment property under similar terms and conditions.

IAS-17: Internal Accounting Standards Committee's Statement no. 17, dealing with standard accounting for leasing transactions.

Lease financing: A financing device whereby a user can acquire use of an asset for most of its useful life, rentals being paid to the lessor and the user being responsible for maintenance, taxes, and insurance.

Lease term: The period of lease. The period for which the agreement of lease shall be in operation.

Lease portfolio: All the leased assets of a leasing company constitute the lease portfolio.

Lessor: The owner of an asset or property who grants it to a firm or a person (called lessee) to use of the assets' services for a specified period of time, usually for an agreed sum of rental. Here, lessor will be the leasing company itself.

Lessee: The user of the services of a leased asset or property for a specified period, usually for an agreed sum of periodic rental payments. A firm or individual(s) may be the lessee.

Lease line: A lease line of credit is similar to a bank line of credit, which allows a lessee to add equipment, as needed, under the same basic terms and conditions without negotiating a new lease agreement.

Lease rental: Lease rental is the lease payment(s) a lessee pays to lessor during the lease period according to the lease contract between the lessor and lessee.

Net Lease: A financial lease in which the executor cost in relation with the asset, e.g., insurance, repairs, maintenance, etc., are to be paid by the lessee.

Performance: Performance is the indicator of financial achievements of a leasing company. It will be determined by analyzing financial statements of leasing companies so that-management and the public can identify the most critical problems inside each leasing compel and develop ways to deal with those problems.

\section{Literature Review}

\subsection{Lease Financing: A Conceptual Framework}

Leasing, in general, is viewed as a method of financing the acquisition of capital equipment. Leasing involves a contractual relationship in which the owner (lessor) or an asset or property grants to a firm or a person (lessee) the use of the asset's services for a specific period of time, usually for an agreed sum of rent (Weston and Brigham, 1978). Leasing, therefore, enables a firm to avail the services of a plant or equipment without making the investment or incurring debt obligation. The firms can use the asset by paying a series of periodic amounts called "lease payments" or "lease rentals" to the owner of the asset 
at the predetermined rates and generally in advance (Harm Levy and Marshall Samuel, 1973).

The payments may be made monthly, quarterly or annually. Often there is no initial deposit or fee. Lease contracts have two parties, namely, Lessor and Lessee. A lessor may be a leasing company, a manufacturer, a subsidiary or an associate of a large business organization. A lessee may be a company, cooperative society, a partnership firm, an individual, government or its agencies (Gupta, 1995, p.2).

1. The lease must have the following basic characteristics viz.:

2. A contract of commercial nature between the lessor (owner) and the lessee (the user);

3. The contract should provide for periodical payment of rentals for using the asset for a fixed term by the lessee;

4. On the expiry of the lease term the hirer should return the asset to the owner or dispose it in the manner desired by the owner.

These characteristics combined together will provide the definition of lease (Verma, 1995, p. 3 1).

\subsection{Origins and Conceptualization of Leasing}

Lease financing was originated in the advanced culture of Middle East with the offering uncultivated land to the Summation people, as stated earlier, in the southern part of what is now called Iraq, about 5000 years ago and the concept of lease financing was developed. For the first time an agreement was signed giving lease a status through the bank leasing in $370 \mathrm{BC}$ in Athens. Greece was also a pioneer in the development of mine lease. All mines in the state of Attic belong to the state and were leased through a single authority.

\subsection{Meaning of Lease Financing}

Lease financing enables leasing or renting the services of an asset rather than buying it. It is a contract whereby the owner of an asset (the lessor) grants to another party (the lessee) the exclusive right to use the asset, usually for an agreed period of time, in return for the payment of rent.

The term lease finance is used in the sense of leasing business assets such as computers, manufacturing plants, ships, aircraft, cars, trucks; etc. This enables a business firm to use the services of an asset without buying it. Lease finance also covers the immovable I property like buildings, factory sheds, office space, land, etc.

\subsection{Classification of Lease}

Leasing (lease) has developed over the years and has assumed different forms at different places and times. Nevertheless, leasing is broadly classified as Equipment Leasing and Real Estate Leasing.

\subsubsection{Equipment Leasing}

Equipment Leasing has been defined as a contract between a lessor and lessee for the hire of specific assets selected from a manufacturer or vendor of such assets by the lessee.

The lessor retains ownership of the assets and the lessee has the possession and use of the asset on payment of specified rentals over a period which will cover the depreciation, interest, and other over heads and a profit margin for the lessor. Equipment leasing is a form of medium and short-term finance and has grown in importance in mid-seventies in UK and late fifties and sixties in USA and has gained popularity in India only in eighties and in Bangladesh only in nineties.

\subsubsection{Classification of Equipment Lease}

Equipment leasing (also called Leasing Finance) is broadly classified into two types, viz.

a. Financial Lease, and

b. Operating Lease.

\subsubsection{1.(a). Financial Lease}

Financial Lease is a long-term lease on fixed assets; it may not be cancelable by either party. It is a source of long-term funds and services as an alternative of long-term debt financing. In financial lease the leasing company buys the equipment and leases it out to the use of a person known as the lessee. It is a full payout lease involving obligatory payment by the lessee to the lessor that exceeds the purchase price of the leased property and finance cost.

According to T. M. Clark, "A financial lease is a contract involving payment over an obligatory period of specified sums sufficient in total to amortize the capital outlay of the lessor and give some profit". Financial lease has been defined by International Accounting Standards Committee as "a lease that transfers substantially all the risks and rewards incident to ownership of an asset. Title may or may not eventually be transferred." Lessor is only a financier and is not interested in the assets (Vernia, 1995, p. 33).

According to Verma, a financial lease must have the following features, viz.

1. The lease is not cancelable by the lessee prior to its expiration date;

2. The lessor may or may not provide service, maintenance, and insurance for the asset; and

3. The asset is fully amortized over the life of the lease.

In addition to the above, a finance lease should meet any one to the following two conditions:

a. The lease has the use of the asset for $75 \%$ or more of the estimated economic life of the leased property;

b. The present value at the beginning of the lease term of the minimum amounts Payable under the lease (exclusive of amounts payable for insurance, maintenance and similar normal outgoing) is at least equal to $90 \%$ of the cost of the leased assets net of investment grants.

In the case of default committed by the lessee in payment of lease money the lessor has recourse to the leased asset as the owner. 


\subsubsection{1.(b) Operating Lease}

Operating lease involves high payments of rentals. It is a non-pay-out lease in which the lessor's obligations include services other than the financing of the purchase price of the leased property such as maintenance, repair, and technical advice. A good example of an operating or service lease is a lease for telephone service wherein the Telephone Department renders all such services for the leased telephone equipment against fixed uniform rentals from the users. The following features usually characterize an operating

\section{Lease:}

1. The lease is cancelable by the lessee priory to its expiration;

2. The lessor provides services, maintenance, and insurance;

3. The sum of all the lease payments by the lessee does not necessarily fully provide for the recovery of the asset's cost;
4. The lessor has the option to recover cost of another party on cancellation of the lease by leasing out the asset again.

Operating lease is in vogue in developed nations of West Europe and also in USA. As a matter of fact, the concept was popularized by the multi-national giants like IBM, and Bell Telephones in USA, which leased their products to buyers for short-spells. Operating lease is more popular where lessor is the null fractures pr dealer in the equipment.

Operating lease is subdivided in to two types -

- $\quad$ Simple operating lease and

- $\quad$ Specialized service lease

The above discussion deals with the simple operating lease. A specialized service lease is an operating lease in which the lessor assumes absolute responsibilities for repair, maintenance, and other obligations of ownership.

However, the basic points of difference between financial lease and operating lease are presented in brief as follows:

Table 1. Difference between Finance Lease and Operating Lease

\begin{tabular}{lll}
\hline Points & Finance 'Leases & Operating Leases \\
\hline $\begin{array}{l}\text { Lessor } \\
\text { Specifications of equipment }\end{array}$ & $\begin{array}{l}\text { Lessor acts as a financing institution } \\
\text { Lessee selects and acts as lessor's agent in ordering it } \\
\text { Period }\end{array}$ & $\begin{array}{l}\text { Lossor purchases and leases it out to the lessee } \\
\text { asset and non-cancelable }\end{array}$ \\
Maintenance & Lessee & Short period and cancelable \\
Component of rentals & Cost of equipment \& interest & Lessor \\
On renewal & Lower rental & Cost of Equipment, interest and maintenance chares \\
Type of Assets & Durable items & Same rental \\
\hline
\end{tabular}

\subsubsection{Real Estate Leasing}

Real estate leasing or a lease of immovable property is a transfer of a right to enjoy such property, made for certain time, express or implied, or in perpetuity, in consideration of a price paid or promised, or of money, a share of crop, service or any other thing of value to be rendered periodically or on specific occasions, to the transfer or by the transferee, who accepts the transfer on such terms. The transferor is called the lessor and the transferee is called the lessee, the price is called the premium and the money, share, service or other things to be rendered is called the rent.

\subsection{Leasing in Global Perspective}

Having a history of about 50 years, leasing is a major force in world capital markets. The size of world leasing' market today is estimated at about US\$350 billion every year, of which about more than 113 is contributed by USA alone. The growth of Asia as major leasing market is remarkable and notable part is accounted for by Japan. Asian market now outstrips that of European tries' rank participating in leasing.

\subsection{Leasing Practices in Developing Countries}

Growth of Leasing, as compared to developed nation, has been slow in developing countries but it is now established as growing industry in many such countries.

During 1981, the Leasing Association of Singapore was formed. It was the Manila based Asian Leasing Association, which includes representatives of Asian countries. The China Oriental Leasing Company commenced operations in 1981 as a joint venture between China and Japan for import of capital equipment. Brazil adopted leasing legislation in 1091. International Finance Corporation was involved between 1977 and 1993 in the formation of forty-seven leasing companies in 26 developing countries viz. In the Republic of Korea (1977), Thailand (1978), the Philippines (1978). Colombia (1980), Sri Lanka (1980), Uruguay (1980), Jordan (1981).

\subsection{Accounting Practice for Leases in Bangladesh}

No specific accounting standards for the lessor, and/or lessee have yet been established in Bangladesh by the competent authority. The Generally Accepted Accounting Principles (GAAP) are being followed under which the leased assets are being shown in the book of the lessor 
while the rental payments are considered as revenue expenditure by the lessee. Accordingly, depreciation on such assets is charged in the books of the lessor although the accounting depreciation may differ from the depreciation stipulated in the tax law (Islam, 1999).

According to Viond Kothari (known as Guru of leasing in India), "Bangladesh has so far; not implemented the International Accounting Standard no. 17. Neither has any similar standard been enunciated by the institute (competent authority). Hence, Bangladesh continues to adopt the operating lease accounting method that is, the lessor capitalizes assets leased, and depreciated in the lessor's books. The entire rentals received by the lessor are treated as the lessor's income, and the lessee's expenses. Such a method leads to a significant distortion, particularly when the leases are structured."

All leasing companies, at present operating in Bangladesh, provide the facility of lease Financing (Financial Lease) only. No one is providing the facilities of Operating Lease though they are adopting the accounting method of the latter rather than the former in preparing the financial statements, which need due attention of the regulatory authority.

\section{Growth of Leasing Business}

\subsection{Growth of Leasing Business in Bangladesh}

Leasing sector in Bangladesh achieved an excellent growth rate of its business over the years. Following tables shows this fact. There are ups and downs in the growth of leasing business over the years. After setting up first leasing company in 1986, it recorded 72.03 per cent growth in real term in 1987 over the previous year. After 1988, the growth rate began to diminish and that had continued up to 1989. The year 1990 witnessed a sudden spurt in the business of leasing companies. The leasing business was up by 56.16 per cent on last year's figure. This has happened due to entry of two new leasing companies into business in 1989. The growth trend then witnessed: ecnne during the 1991 and1992 period, increasing again in 1993 and 1994. The growth rates were quite pronounced in 1995 and 1996. The growth rates were 62.29 per cent in real term in 1995 over the previous year and that was 61.4 per cent in 1996. This was due to the fact that entry of more leasing companies the market and of aggressive operation of new leasing companies. The rates were irregular in the second half of the 1990s. However in 1998, leasing sector of Bangladesh experienced a drastic diminished growth trend with only 2.65 per cent in real term previous year's figure, although two new leasing companies made entry into the leasing market. This diminished trend was witnessed possible due to the unprecedented flood in 1998 when most economic activities virtually came to stand still. However in 1999, the industry showed signs of recovery registering 30.12 per cent growth. The growth rate of leasing business then rose to 30.89 per cent in real term 2000, decreased again in 2001 to 24.09 per cent in real term. Leasing business in nominal figure gave almost the same trend and variations over the years.

The leasing industry has, therefore, consistently increased since 1986 with some variations. The sector accounts for 38.26 per cent in nominal term and 32.18 per cent in real term Compound Annual Growth Rate (CAGR). Moreover, business has increased by around 141 times in nominal term and 71 times in real term over the period under study. This trend is quite encouraging for the leasing industry. However, reasons for slow growth rates of leasing business in some years were results of mainly ups and downs of industrial growth, diversification of leasing companies into other activities and withdrawal of tax benefits.

Table 2. Leasing Contracts

\begin{tabular}{ccccc}
\hline Year & $\begin{array}{c}\text { No of leasing } \\
\text { companies }\end{array}$ & $\begin{array}{c}\text { Amount (in } \\
\text { million) }\end{array}$ & Index & $\begin{array}{c}\text { Growth } \\
\text { Rate }\end{array}$ \\
\hline 1996 & 1 & 733 & 100 & - \\
1997 & 1 & 1261 & 172 & 72.03 \\
1998 & 1 & 1637 & 223 & 29.65 \\
1999 & 3 & 32026 & 276 & 23.76 \\
2000 & 3 & 31357 & 431 & 56.16 \\
2001 & 3 & 4244 & 579 & 34.33 \\
2002 & 3 & 4825 & 658 & 13.64 \\
2003 & 4 & 5887 & 803 & 22.00 \\
2004 & 4 & 7718 & 1053 & 31.13 \\
2005 & 6 & 12530 & 1709 & 62.29 \\
2006 & 11 & 20223 & 2759 & 61.43 \\
2007 & 14 & 25174 & 3434 & 24.46 \\
2008 & 16 & 24508 & 3343 & 2.65 \\
2009 & 16 & 31887 & 4350 & 30.12 \\
2010 & 17 & 41737 & 5694 & 30.89 \\
2011 & 17 & 51800 & 7066 & 24.09 \\
2012 & 22 & 58000 & 8059 & 28.01 \\
\hline
\end{tabular}

Leasing has been growing in popularity since 1995 as an alternative form of financing. The following Table-3 \& figure-1 shows the growth of leasing contracts over the years.

Table 3. Growth of Contracts

\begin{tabular}{ccc}
\hline Year & Contract (Tk). Million) & Growth (\%) \\
\hline 1995 & 41 & - \\
1996 & 82 & 98.7 \\
1997 & 117 & 41.5 \\
1998 & 158 & 36 \\
1999 & 262 & 65.4 \\
2000 & 365 & 39.4 \\
2001 & 415 & 13.7 \\
2002 & 525 & 26.4 \\
2003 & 741 & 41.2 \\
\hline
\end{tabular}




\begin{tabular}{ccc}
\hline Year & Contract (Tk). Million) & Growth (\%) \\
\hline 2004 & 1254 & 69.2 \\
2005 & 2083 & 66.2 \\
2006 & 2617 & 25.6 \\
2007 & 3331 & 27.3 \\
2008 & 4187 & 25.7 \\
2009 & 5005 & 19.5 \\
2010 & 6500 & 23 \\
2011 & 7500 & 15 \\
2012 & 11291 & 50 \\
\hline
\end{tabular}

Source: Financial Institutions Department, Bangladesh Bank

Leasing Contract

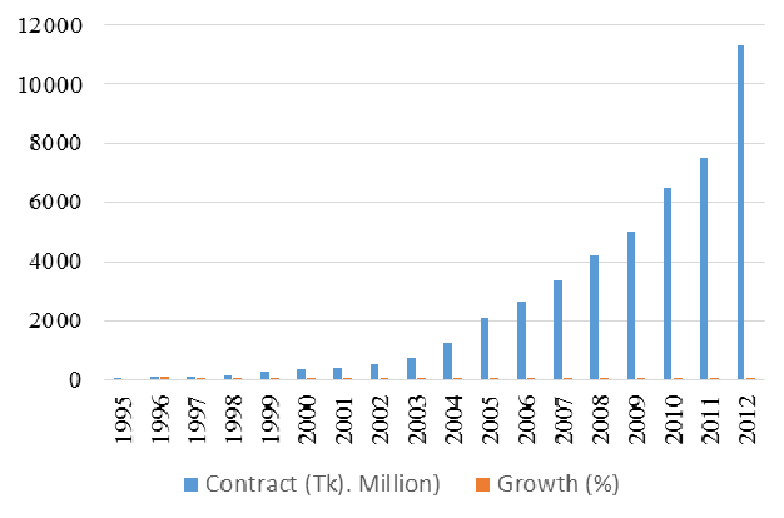

Fig 1: Leasing Contract

The leasing execution in Bangladesh for the past 16 years are given below -

Table 4. Growth of Execution

\begin{tabular}{ccc}
\hline Year & Contract (Tk. Million) & Growth (\%) \\
\hline 1996 & 31 & - \\
1997 & 113 & 262.4 \\
1998 & 131 & 15.8 \\
1999 & 233 & 78.6 \\
2000 & 248 & 6.3 \\
2001 & 397 & 59.8 \\
2002 & 472 & 19.1 \\
2003 & 599 & 26.8 \\
2004 & 1027 & 71.6 \\
2005 & 1756 & 70.9 \\
2006 & 2389 & 36 \\
2007 & 2794 & 17 \\
2008 & 3669 & 31.3 \\
2009 & 4950 & 34.9 \\
2010 & 6180 & 24.8 \\
2011 & 8000 & 29.4 \\
2012 & 9750 & 21.8 \\
\hline
\end{tabular}

Source: FI Department of Bangladesh Bank Figure-2: Growth of Leasing Execution

\section{Leasing Execution}

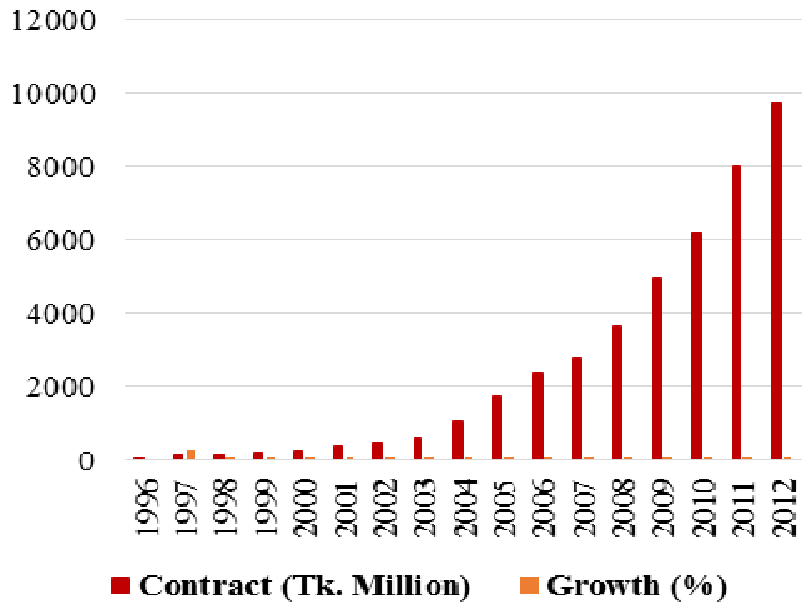

Fig 2: Leasing Execution

\subsection{Market Share of Leasing Companies of Bangladesh}

The countries leasing industry grew in the year 2009 at an estimated growth rate of $>4.2 \%$ over the previous year mainly due to expansion of the market following the aggressive operation of the new leasing companies. with the arrival of more leasing companies as well as banks offering similar service, the market is becoming much more competitive and the former concentration of market share is being spread over the companies. The tight availability of operation funds in the backdrop of increasing cost of found in the market as well as increasing competition in making it difficult for the companies to operate smoothly.

The overall market share of existing leasing companies of Bangladesh in 2008 and 2009 are shown separately in pie charts in Figure-3. A comparative study of lease market share of existing leasing companies (participating in lease financing) is also shown in Table -5 as follows.

Table 5. Market Share of Leasing Companies of Bangladesh in 2011 and 2012

\begin{tabular}{cccccc}
\hline SI No & $\begin{array}{c}\text { Name of } \\
\text { Leasing } \\
\text { Company' }\end{array}$ & \multicolumn{2}{c}{ Lease Market Share (\%) } & $\begin{array}{c}\text { Composite position } \\
\text { in the Lease Market } \\
\text { Share }\end{array}$ \\
\hline 1 & IDLC & 29 & 23.4 & 26.2 & 1 st \\
\hline 2 & ULC & 22 & 19.9 & 20.95 & 2nd \\
3 & PLC & 10 & 9.1 & 9.55 & 3rd \\
4 & IPDC & 9 & 5.1 & 7.05 & 6 th \\
5 & GSPFCL & 8 & 6.1 & 7.05 & 4 th \\
6 & ILFSL & 6 & 7.1 & 6.55 & 5 th \\
& OTHERS & 16 & 29.3 & 22.65 & \\
\hline & Total & $\mathbf{1 0 0}$ & $\mathbf{1 0 0}$ & $\mathbf{1 0 0}$ & \\
\hline
\end{tabular}

Source: Calculated from the records of Bangladesh Bank as well as annual reports of leasing companies. 


\section{Composite}

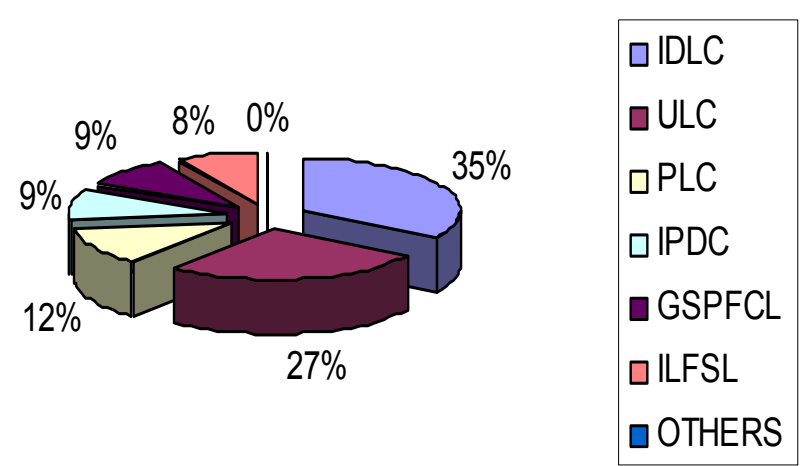

Fig 3: Market Share of Leasing companies of Bangladesh

From the above table it is clear that the lease market share of leasing companies, presently participating in lease financing, the highest market share was captured by IDLC (29.00\% in 2011 and 23.40 in 2012).

IDLC's market share in 2012 was $23.4 \%$, which is greater than ULC by $3.5 \%$. Accordingly, in 2012 ULC, PLC, ILFSL, GSPFCL, IPDC captured the 2nd, 3rd, 4th, 5th, and 6th position in lease market share whereas, in 2011 ULC, PLC, IPDC, GSPFCL, ILFSL got that positions respectively. However, a composite lease market share of leasing companies is developed by calculating the simple average of 2012 and 2011 Lease market share of the respective market players (leasing companies) to see their overall lease market position in the leasing industry. This composite lease market share of a company is relatively stable than its market share of a particular year. In the composite lease market share, as shown in the Table- 2 above, IDLC stood 1st. And the 2nd, 3rd, 4th and the position are captured by ULC, PLC, ILFSL and so on. This composite lease market share is shown graphically in the Figure-3.

\subsection{Growth of Leasing Companies}

In 1952, the United States Leasing Corporation was set up followed by Canadian subsidiary- Canada Dominion Leasing Corporation in June 1959. In 1960, Mercantile Leasing-Company was "established in London by Mercantile Credit Company. And thus, the leasing activity spread in Western European nations like France, Italy, Germany, etc. In 1963, one of the largest leasing companies in the world known as Orient leasing Company was established in Japan. It spread to other parts of the world. In India, leasing was adopted in modern sense as a professional financial service with the startup in 1973 by. The first leasing company of India set up in madras, and in 1980s onwards, there are about 500 leasing companies (Verma, 1995, p.2). In Bangladesh, the first leasing company, industrial development leasing company of Bangladesh (IDLC) was established in 1986 and in the end of 2001, 17 leasing companies was licensed.

\subsection{Growth of Leasing in Developed Nations}

There are two principal reasons which contributed the development of equipment leasing in the developed countries, namely: (1) the high rate of technological obsolescence of most of the industrial equipment which made "use of the equipment" through leasing a better proposition than ownership; (2) the earning capacity of the equipment has primary importance to the psychological factor of ownership. Government in the development countries also encourages the Equipment Leasing concept by providing specific monetary and fiscal incentives for companies to lease out equipment.

The first independent leasing company was The United States Leasing Company, incorporated in 1952. It provided successful, and the industry spread to England, with the establishment of the Mercantile Leasing Company in 1960. By the middle of the 1960s, leasing industries were flourishing throughout Western Europe, the United States of America and Japan.

Varying legal treatment, circumstances and tax policies have made leasing more appealing in some country than in others. For example, in Austria financial leases on real estate according for about one-fourth of growth of a leasing industry, whereas elsewhere this is rare. In Western Europe about one-third of leasing business is devoted to automobile leasing another third to industrial machinery. About one-fifth of the business represents computers and office machines, with the rest divided up among ships, aircraft, railroad, railroad rolling stock, and other miscellanies. The automotive portion in Australia is a bit larger and in Canada the industrial portion is smaller, but the aircraft portion is larger. In Japan, however, computers and office machines represents more than two thirds of the market, about one fifth relates to industrial machines and the rest is miscellanies, including a fairly large portion for medical equipment.

\subsection{Motivational Factor for growth of Leasing}

The motivational factor behind the growth and development of leasing finance concept in developing countries with respect to particular lessor and lessee interests, which are summarized below:

- Increased competitiveness for financial institutions;

- Increased competitiveness for suppliers and manufacturers;

- $\quad$ Profit of the "independent" leasing companies;

- Attraction of lower ultimate cost or increased financial flexibility for lessee;

- Tax laws benefits;

- Better planning for development of leasing industry;

An attempt has been taken to present an overview of studies conducted all over the world in the field of lease financing which have given a picture of growth of leasing in the world. These studies have been conducted in the world both theoretical and empirical level. The main focuses of these studies have been on three aspects of 
leasing in which one was the Factors Responsible for the Growth of Leasing.

Starting with the pioneering work by Vancil and Anthony (1959), several studies have been conducted throughout the world focusing on Factors Responsible for the Growth of Leasing business. Some of the prominent studies are those Of Marrah (1968), Fawthrop and Terry (1976), Deutsche Leasing (1976) (see Herst, 1983), Sykes (1977), Anderson and Martin (1977), (see Altman, 1986), macguan (1974), Martin (1981), (see Mayes and Nicholas, 1988), Ferrara, Thies and Dismith (1979), Ronard Ma (1981), Stephens (1983), Jal'iles and Peterson (1984); Smith and Wakeman (1985), John Woodhouse (1985), and Foreman Tony (1985).

The most important reasons accounting for the growth of leasing in the world appear to be:

i. Tax benefit;

ii. Off balance sheet financing;

iii. Conserves working capital;

iv. Transfers risk of obsolescence;

v. Preserves debt capacity; and

vi. Serves as a hedge against inflation

\section{Conclusion}

Leasing industry is a prosperous sector in Bangladesh. The leasing companies on the average are doing pretty well since inception in this country. Leasing has gained its popularity for several reasons. The first and most important of all is that leasing can be thought of as an alternative source of fund which is most of the cases cheaper, and for the companies which don't have a high credit rating or a visible positive past track record, this may be the main source of financing. Another thing is, lease is an alternative to investment. If you need a particular asset for running or expanding your business, you may choose to lease it rather than purchase it. And you can cancel the lease options in the face of changing macroeconomic factors, such as obsolescence, new technologies, changing business needs or market conditions etc. Lease is nowadays treated by the developed markets as a provider of $100 \%$ financing and they have a notion that lease displaces debt. Leasing actually reduces the leverage needs of a firm.

We can understand that the leasing market is still very small in Bangladesh and the actual potential market is highly untapped. Since people are not well aware of different types of lease products, they look for other alternative before leasing. But now it's time for us to break away from tradition and utilize leasing in our businesses fully so that we can realize its benefits. We believe that leasing sector in Bangladesh will grow, as people become more knowledgeable and more willing to look for alternative sources of financing.

\section{References}

[1] Altman, Edward Handbook of Corporate Finance, John Wily and Sons, New York, 1986 pp11-41.

[2] Choudhury, A. Quadir, "Leasing in Bangladesh- An Overview", The Bangladesh Observer, 1999, December 03, Dhaka.

[3] Anderson, Paul, F. and Martin J. D. "Lease vs. Purchase Decision: A Survey of Current Practices", Financial Management, Vol.6, Spring, pp.1979, 41-47.

[4] Choudhury, T. A. "An evaluation of the performance of commercial banks in Bangladesh”, Ph.D. thesis. 1990.

[5] Clark, T. M. Leasing, McGraw Hill, London, 1976.

[6] Cooper, R. A. and A. J. Weeks, Data Models and Statistical Analysis, Haritage Publish, New Delhi, India, 1983, P-400.

[7] Fabozzi, Frank J. Equipment Leasing -A Comprehensive Guide for Executives, Dow Jones - Irwin Inc., USA, 1981, P-248. 